Ŭ̆ur Buğra Çelebi

Levent Bilgili

Bilkutay Yllmaz

http://dx.doi.org/10.21278/brod70101

ISSN 0007-215X

eISSN 1845-5859

\title{
LIFE CYCLE COST ANALYSIS FOR THE YAW DAMPING SYSTEM OF A WARSHIP FROM A FINANCIAL VIEWPOINT
}

UDC 629.5.017.2: 629.5.017.23:

Professional paper

\begin{abstract}
Summary
Life cycle assessment (LCA) is implemented to various processes with a strict exception for naval platforms and warships. Thus, the recent studies for life cycle analysis of military ships are limited. LCA is a holistic method based on developing an optimization between environmental performance, cost-benefit balance and usability. LCC is a supporting subsection of LCA implemented to the analysis in order to calculate the probable costs during whole phases of a product. In this study, LCA and LCC are implemented to a naval platform and a calculation, which is based on escalation, is realized to compare the maintenance costs and initial cost for all life cycle of the platform. A generic warship is selected and yaw damping system of the ship was chosen for implementation of LCA and LCC. It is accepted that the systems and devices are used 1500 hours during cruising and 7260 hours during hoteling. First, the initial cost of yaw damping system is calculated, then, costs of long term maintenance with and without escalation are considered. In the final part, the profit gained by recycling of yaw damping system is calculated. The results has shown that an extra cost of 38 $\%$ and $19 \%$ for operation and maintenance and total cost, respectively, must be added according to escalation calculations. While initial cost and operation and maintenance costs have $51 \%$ and $49 \%$ of total costs without escalation, the share of initial cost decreases to 43 $\%$ and the share of operation and maintenance increases to $57 \%$ with the utilization of escalation.
\end{abstract}

Key words: life cycle assessment; life cycle cost; naval platforms; recycle; escalation

\section{Introduction}

Navies have great importance for both protecting the coastline and prevent illegal activities across territorial waters. Naval platforms are exceptions for almost all international rules and regulations, which particularly involve the impacts of ships on the human health and environment. Besides, because navies are uncompromisable defence systems, cost analysis is generally ignored to some extent. Thus, implementing approaches such as Life Cycle Assessment (LCA) and Life Cycle Cost (LCC) to naval platforms is not usual. On the other hand, these holistic methods are instrumental and may provide significant benefits. Planning the ship's all life cycle and using ship life cycle assessment (SLCA), which is a unique 
combination of LCA, and LCC not only ensure excellence in war tasks but also provide a remarkable reduction of emissions and wastes. Conducting SLCA may result in a longer service period and minimize the running costs during all phases.

[1] presented a general view for main topics of a life cycle of a product. He touched the types of LCA and its main sections briefly and specified the holistic approach of LCA, generally. In this study, modern ship design approach for green shipping is also explained and energy consumption and environmental impacts of ship LCA is mentioned. [2] indicated that ports and shipping activities are one of the most influential players for developing and being competitive in Europe. The authors also stated that the ever-growing shipping sector causes significant environmental impact. They recognized the importance of a life cycle assessment study in order to identify and measure the environmental impacts of ship-related wastes. It is derived from this study that carcinogens and heavy metals have the greatest impact on environmental issues. It is also indicated that recycling waste oil and fuels may reduce the harmful effects on the environment. [3] compared the two types of materials used in superstructure by the help of LCA methods and investigated the environmental impacts. By using different LCA analyze methods and software; he indicated that the environmental impacts of the composite superstructure are far less than steel superstructure. [4] indicated that LCA is used in order to determine the environmental impacts of different industries. [5] explained that LCA is a method used for determining the consumption and harmful effects of a product. The authors also stated that LCA consists of all phases of a product from the cradle to grave. [6] also presented the effects of LCA on reducing the emissions and discharges during operation and highlighted LCA method in terms of waste management. [7] indicated that growing global race in production industry forces system generators and providers to estimate and optimize the LCC of the whole system process in terms of performance, safety, reliability and maintainability. In this context, the authors stated that system providers should consider the whole process in order to ensure customer requests from the concept design phase to sale phase. [8] expressed that many production companies adopted LCA to evaluate the environmental performances clearly. However, it is also indicated that due to the complexity of the ship's systems and manufacturing processes it is almost impossible to use LCA properly for ships. The authors investigated the manufacturing methods for different types of ships and developed database software to utilize LCA for ships. [9] investigated the role of the material efficiency to reduce $\mathrm{CO}_{2}$ emissions during ship manufacture in a life cycle perspective. They resulted that designing and manufacturing the $100 \%$ of the hull with reusable materials reduce $\mathrm{CO}_{2}$ emissions by $29 \%$. [10] investigated the implications of a new-build hybrid power system for Ro-Ro ships from a sustainability and life cycle perspective. The authors used a bottom-up integrated system approach to optimize operational profile and considered the manufacturing processes, mass breakdown and end of life management plans. They concluded that because the impacts of hybrid systems are significant, a proper control system must be implemented. [11] studied on ship air emissions from a life cycle perspective. The authors presented a mathematical framework to provide a holistic assessment of airborne emissions for ships. [12] utilized LCA to investigate the steel in ship recycling industry in Bangladesh. They focused on the evaluation of energy use and emissions during different phases of LCA of the steel. The authors resulted that rerolling and cutting activities are the primary sources of emissions and they offered using protective gear to reduce the emissions.

Besides shipping, LCA and LCC have a great area of utilization in various subjects. [13] used LCA to assess the environmental impacts of freshwater thermal pollution. [14] studied the implementation of LCA in Environmental Impact Assessment (EIA) procedures. For their study, the authors investigated two wastewater treatment plant. Four EIA steps, which could theoretically benefit from LCA implementation, are identified: (a) the 
environmental comparison of alternatives, (b) the identification of key impacts, (c) the impact assessment, (d) the impact of mitigation measures. LCA is implemented to each step for specific goals. [15] compared different methods to quantify greenhouse gas (GHG) emissions of cropping systems using LCA. The authors aimed to compare several methods for estimating $\mathrm{CO}_{2}$ and $\mathrm{N}_{2} \mathrm{O}$ emissions and to estimate the relative contribution of soil GHG emissions to the overall Global Warming Potential (GWP). [16] prepared a critical review on Building Information Modeling (BIM) based LCA method application to buildings. The authors reviewed recent studies focused on BIM-based LCA and carried out a methodological analysis for their integration, focusing on the contribution of BIM to simplify data input and optimize output data and results during LCA application to buildings. [17] focused on different modeling options in terms of database choices, system boundary definitions and replacement scenarios of building materials during LCA of the buildings. [18] studied on LCA data quality and the authors concluded that LCA data quality assessment approach is not adequate for enterprise-scientific data because it focuses uniquely on industry average data. They offered some suggestions for allowing consistent data quality assessment that would ensure the usefulness of LCA information. [19] proposed a method aimed to support LCA for evaluation of environmental benefits achievable by light-weight design solutions for the automotive sector. The study mainly focused on developing fuel reduction value coefficient based on weight induced fuel consumption. [20] investigated a shipping container home in terms of LCA and Life Cycle Environmental Impacts (LCEI). The authors used LCA to evaluate six LCEI category indicators: Cumulative Energy Demand (CED), water use, solid waste, global warming potential (GWP), acidification potential, eutrophication potential. [21] implemented LCC to compare the costs of different electrical energy storage systems. [22] studied probabilistic LCC analysis for renewable and non-renewable power plants. The authors developed two probabilistic methods to assess the costs of power plants. [23] utilized LCC to analyze green-building implementation using timber applications. LCC provided the most suitable timbers for different applications in terms of green-building. [24] evaluated the effectiveness of separating layers in railroad track structure using LCC. The authors combined LCC with reliability analysis. [25] integrated LCA and LCC and applied the combined method to the design process of a hybrid train. [26] combines LCA and LCC in Eco-CareMatrix in order to evaluate the performance of a modernized manufacturing system for glass containers.

[27] presented a novel experimental measurement method to predict wave induced motions and load responses in real sea waves. This method consists of tests, which have been realized with large-scale models under natural environmental conditions. The study focused on the investigation of the ship hull against pitch, roll, bow acceleration and vertical bending moment (VBM) motions. The authors concluded that the difference between the results of experimental and numerical methods of short-term predictions in combined average sailing conditions is less than $8 \%$. In [28] the authors adopted a buoy wave height meter to measure and analyse the coastal wave environment. The seakeeping performance experiments conducted for the same tonnage of round bilge vessel and the deep-V hybrid monohull of large-scale vessel model under the coastal wave conditions. The results show that the difference between the motion characteristics of large-scale vessel models in the coastal wave environment and small-scale vessel models in tank is significant. [29] proposed a computerbased system on automatic elimination of ship design parameters for seakeeping performance. According to the system, first, the weakest parameter is identified and then, these parameters are eliminated for the best seakeeping performance.

Price escalation method is used by [30] for non-linear water tariffs for domestic uses in Spain. The authors analyse the determinants of the price escalation of water supply tariffs in 
Spain. They resulted that tariff escalation is influenced by environmental factors and decision makers' strategic choices. [31] prepared a review on the impact of tariff escalation on the environment. The author mainly focused on the impact of escalating tariffs on the allocation of production and processing between exporters and importers, comparison of the environmental impacts of primary production and processing, the impact of increased income from removing tariff escalation on environmental protection expenditures, the environmental impact of decreased transport to freight.

The methods and models of LCA are presented in the technical report of North Atlantic Treaty Organization (NATO) Research and Technology Organization. Cost prediction methods and models are exemplified in the report and a comprehensive guide is developed for LCC applications of multi-national military projects [32]. NATO also identified the life cycle costs based on generic cost allocation and presented detailed information on these costs. Thus, NATO, by considering the effects of scheduling and efficiency, takes an active role in cost application methods [33]. In another report, NATO explained the subcomponents of warships and costs, in detail. The report presents the costs during the phases of the job definition of ships, pre-feasibility study, project definition, design and development, manufacturing and inventory [34]. US Department of Defence indicated that due to the limited labour force and sources of navies, life cycle cost is an important management tool for efficient source allocation. The main purposes of the document are to reveal the total cost estimation and annual expenses of the ships during design, operation, repair and maintenance processes and to reduce the costs by using LCA methods [35].

In this study, a generic warship operational usage scenario is demonstrated. It is estimated that systems and devices are used 1,500 hours during cruising and 7,260 hours during hotelling. Vital and supporting systems and devices are run 7/24.

\section{Materials and Methods}

LCA realizes the evaluations with successive and independent processes perspective and it is used for estimating the total environmental impacts caused by all phases of life cycle including the processes not considered in the traditional analysis [36]. LCA can be identified by the help of 6 RE philosophy: Re-think (detailed analyses for the product and its function), re-duce (minimizing the raw material and energy consumption), re-place (using less harmful materials instead of more harmful ones), re-cycle (recyclable materials are chosen), re-use (the product is produced as reusable), re-pair (the product is produced as appropriate for repair) [37]. According to [38], a traditional LCA process can be separated into four phases, which are interrelated with each other. In the first phase, the goal and scope of the study and analysis must be identified and determined. Then, the inventory analysis of the system or the product must be created. The third phase includes the calculations for impact assessment of different stages in the life cycle. Interpretation phase is related to other phases and provides the relationships between them.

Cost escalation, which is used in this study to calculate the real costs of a ship's system during its life cycle, refers to the increase in the amount of money required to sustain a project over and above the original budgeted amount. Cost escalation is also identified as a result of problems such as delay in land acquisition, unexpected problems in the supply of raw materials, illegal encroachment during project implementation. It is also stated that delays between the planning stage and actual implementation of projects are significant problems resulting in cost escalation [39].

The formula for total system cost is presented in Equation 1. The equation includes various types of expenses which are explained below.

$$
C=C_{R}+C_{i}+C_{0}
$$


where;
C: Total system cost
$\mathrm{C}_{\mathrm{R}}$ : Research and development cost
$\mathrm{C}_{\mathrm{i}}$ : Investment cost
$\mathrm{C}_{\mathrm{O}}$ : Operation and maintenance cost

\section{Results and Discussion}

There are four levels for maintenance and repair processes of a ship. Level 1 (Consumer Level) involves planned maintenances which can be operated by crew; Level 2 (On-Site Level) involves planned maintenances which must be realized by the help of repair mechanics; Level 3 (Shipyard Level) consists of informing shipyard personnel in order to perform construction and assembly processes uneventfully and certification process in accordance with international standards for construction and repair; Level 4 (Manufacturer Level) consists of planned maintenances, malfunction localization, repairs and tests/settings which cannot be run by the navy.

In this study, a generic operation concept of a ship is considered, the maintenance periods of different parts of the ship, the levels and processes of these maintenances and the activities and phases of a warship during its life-cycle are investigated.

\subsection{Scenario-1 Yaw Damping System}

In this sub-section, the required maintenances, maintenance periods and durations of a yaw damping system are explained. Yaw damping is a system consists of active fin equipment which is driven by hydraulic drives. Pitch, heave and roll are three dangerous types of movements, which have adverse effects on load, passengers and ship capabilities, which occurs in rough sea conditions. These movements restrict manoeuvring and shooting ability of warships. Yaw fins move in opposite direction to yaw motion in order to help the ship keep still on water surface.

Two LCA scenarios are considered in this study for consumables and replacement parts of yaw damping system. In consumables scenario, lubricating oil, which is used in hydraulic systems and main bearings, and high-pressure hoses are considered as the most important consumables. While lubricating oil is changed annually, high-pressure hoses are changed quadrennially. Thus, during a life cycle of a ship, which is accepted as 35 years, roughly, lubricating oil and high-pressure hoses are changed 35 and 9 times, respectively. Recommended recycling methods are reprocessing in appropriate recycling facilities.

Scenario for replaced parts includes fin plates, electric motor bearings and valves. While bearings and valves are changed quadrennially, fin plates are changed during half-life modernization. Recycling recommendation for all types of parts is reprocessing in appropriate recycling facilities. Various types of equipment such as oil, sealing components, vibration dampers and hoses replaced with new ones during maintenances. Recycling this equipment may provide side income and minimize the deleterious impacts on the environment.

Hourly wage is assumed as $31 €$ in man-hour calculations. An escalation calculation, based on the data obtained from the European Central Bank, is realized in order to present the net values of cost for an estimated 35 years life-span of a warship.

Long-term maintenance costs for different levels are estimated as 13,478, 638,591, 46,132, 11,377 and 709,580 $€$ for support, calibration, measure and test tool, Level 1, Level 2 and Level 3, respectively and annually. That means the maintenance of a ship causes a cost $2,128,734 €$ during approximately 35 years life-span. On the other hand, when escalation is implemented to the processes, the maintenance costs for different levels are calculated as $23,683,1,020,257,56,194,15,567$ and $1,116,702 €$ for support, calibration, measure and test 
tool, Level 1, Level 2 and Level 3, respectively and annually. The total maintenance cost is estimated as 3,350,106€ during 35 years life-span.

Figure 1 presents the distribution of systems on which yaw cost analysis is implemented.

\begin{tabular}{|c|c|c|c|c|c|c|c|c|}
\hline \multicolumn{9}{|c|}{ Ship } \\
\hline \multicolumn{4}{|c|}{ Hull } & \multicolumn{5}{|c|}{ Machinery } \\
\hline $\begin{array}{c}\text { Reverse } \\
\text { osmosis } \\
\text { and drinking } \\
\text { water U/V } \\
\text { filter }\end{array}$ & $\begin{array}{c}\text { Wastewater } \\
\text { and } \\
\text { pollution } \\
\text { control } \\
\text { system }\end{array}$ & $\begin{array}{l}\text { Helicopter } \\
\text { transfer } \\
\text { system }\end{array}$ & $\begin{array}{l}\text { Cooling } \\
\text { system }\end{array}$ & JP-5 system & $\begin{array}{l}\text { Rudder } \\
\text { system }\end{array}$ & $\begin{array}{l}\text { Bilge } \\
\text { separator } \\
\text { system }\end{array}$ & $\begin{array}{c}\text { Yaw } \\
\text { damping }\end{array}$ & $\begin{array}{l}\text { F-76 fuel } \\
\text { separator } \\
\text { and } \\
\text { lubricating } \\
\text { oil purifier }\end{array}$ \\
\hline
\end{tabular}

Fig. 1 Distribution of systems for yaw cost analysis

\subsection{Profit Gained by Recycling of Yaw Damping System}

A sample maintenance scenario for yaw damping system is presented and some suggestions for recycling/reusing of consumables and replaced parts are made. The prices of scrap and wastes are predicated on pricing policy of Europe. Table 1 presents the gained profit by implementing recycling processes for yaw damping system.

Table 1 Profit gained by recycling of yaw damping system

\begin{tabular}{|l|l|l|l|l|l|}
\hline Consumables /Parts & Amount & Unit Price & Period & Total Amount & Gained Profit \\
\hline Oil & $\sim 4201$ & $0.86 € / 1$ & Annually & 14,7001 & $12,642 €$ \\
\hline Steel Sheet & $\sim 4 \mathrm{t}$ & $210 € / \mathrm{t}$ & $\sim 17$ years & $\sim 8 \mathrm{t}$ & $1,680 €$ \\
\hline Hose (Plastic) & $\sim 0.4 \mathrm{t}$ & $1,645 € / \mathrm{kg}$ & Quadrennially & $3.6 \mathrm{t}$ & $5,922 €$ \\
\hline Valves (Stainless Steel) & $\sim 0.3 \mathrm{t}$ & $835 € / \mathrm{t}$ & Quadrennially & $2.7 \mathrm{t}$ & $2,255 €$ \\
\hline TOTAL & & & & & $22,499 €$ \\
\hline
\end{tabular}

When escalation is implemented on profit gained by recycling process, the net profits for different consumables and parts are presented as follows: 14,316.89, 2,007.32, 6,973.76 and $2,586.38 €$ for oil, steel sheet, hose and valves, respectively during 35 years life-span of the ship. Thus, the total net profit is calculated as $25,704.35 €$ for all consumables and parts.

\section{Conclusion}

Analyzing the costs for the system from a holistic viewpoint shows that the initial investment cost, which consists of research and development cost, is approximately equal to the operation and maintenance costs occurred during all life cycle. Considering the real value of costs in accordance with the data of the European Central Bank, it is also estimated that operation and maintenance costs may be much more than the initial investment cost. While initial investment cost has $51 \%$ of total costs, operation and maintenance costs have $49 \%$, without using escalation, it can be seen that these ratios change when escalation method is implemented. In this case, while the initial investment cost decreases to $43 \%$, operation and maintenance cost increases to $57 \%$. Thus, it can be deduced that an extra cost, which is as much as the initial investment cost at least, may occur. 
The total cost of all systems is calculated as 9,411,780.04 $€$, whose $2.41 \%, 48.6 \%$ and $48.98 \%$ are expenditures for research and development, investment and operation and maintenance, respectively. When escalation calculation is implemented on the costs, the total cost of all systems is estimated as $11,161,197.32 €$, in which research and development, investment and operation and maintenance processes are responsible for $2.03 \%, 40.98 \%$ and $56.97 \%$, respectively. It is also observed that escalation calculation only has effects on operation and maintenance process. It can be seen that there is approximately 1,750,000€ difference between two cases, with and without escalation calculation. This amount brings an extra cost by $38 \%$ and $19 \%$ for operation and maintenance and total cost, respectively. Thus, it is accepted that considering possible extra costs in cost analysis calculations is much more beneficial and realistic.

The results of cost analysis show that operation and maintenance cost is almost equal to initial investment cost. Analyzing the costs with escalation formulas show that the realistic values may be higher than initial investment cost. An extra cost by $38 \%$ and $19 \%$ for operation and maintenance and total cost, respectively, must be added according to escalation calculations. While initial cost and operation and maintenance costs have $51 \%$ and $49 \%$ of total costs without escalation. The share of initial cost decreases to $43 \%$ and the share of operation and maintenance increases to $57 \%$ when escalation is applied. These changes in amounts show that a realistic life cycle cost analysis from the cradle to the grave perspective can provide a better budget prediction. Moreover, recycling and reusing are extremely remarkable solutions for reducing waste energy and sources.

\section{REFERENCES}

[1] Shama MA (2005). Life cycle assessment of ships, Maritime Transportation and Exploitation of Ocean and Coastal Resources, Taylor \& Francis Group, London, ISBN: 0-415-39036-2

[2] Zuin S, Belac E, Marzi B (2009). Life cycle assessment of ship-generated waste management of Luka Koper, Waste Manag, 29:3036-3046, https://doi.org/10.1016/j.wasman.2009.06.025

[3] Hou Q (2011). Life cycle assessment of cruising ship superstructure, Master Thesis in Sustainable Development, Uppsala University, Sweden

[4] Chatzinikolaou SD, Ventikos NP (2014). Applications of life cycle assessment in shipping, $2^{\text {nd }}$ International Symposium on Naval Architecture and Maritime, Istanbul, Turkey

[5] Bilgili L, Celebi UB (2012). Waste management model in ship life cycle assessment, Technical Congress on Naval Architecture and Maritime, Istanbul, Turkey, 525-533 (in Turkish)

[6] Bilgili L, Celebi UB (2013). Life cycle assessment approach of waste management for ship operation, Sustainable Intelligent Manufacturing, Lisbon, Portugal, 269-271, https://doi.org/10.1201/b15002-52

[7] Carpentieri M, Papariello M (2006). A life cycle cost framework for automotive production lines, $13^{\text {th }}$ CIRP International Conference on Life Cycle Engineering, Leuven, Belgium

[8] Kameyama M, Hiraoka K, Sakurai A, Naruse T, Tauchi H (2004). Development of LCA software for ships and LCI analysis based on actual shipbuilding and operation, $6^{\text {th }}$ International Conference on EcoBalance, Tsukuba, Japan

[9] Gilbert P, Wilson P, Walsh C, Hodgson P (2017). The role of material efficiency to reduce $\mathrm{CO}_{2}$ emissions during ship manufacture: A life cycle approach, Mar Policy, 75:227-237, https://doi.org/10.1016/j.marpol.2016.04.003

[10] Ling-Chin J, Roskilly AP (2016). Investigating the implications of a new-build hybrid power system for Roll on/Roll-off cargo ships from a sustainability perspective-A life cycle assessment case study, Appl Energy, 181:416-434, https://doi.org/10.1016/j.apenergy.2016.08.065

[11] Chatzinikolaou SD, Ventikos NP (2015). Holistic framework for studying ship air emissions in a life cycle perspective, Ocean Eng, 110:113-122, https://doi.org/10.1016/j.oceaneng.2015.05.042 
[12] Rahman SMM, Handler RM, Mayer AL (2016). Life cycle assessment of steel in the ship recycling industry in Bangladesh, J Clean Prod, 135:963-971, https://doi.org/10.1016/j.jclepro.2016.07.014

[13] Raptis CE, Boucher JM, Pfister S (2017). Assessing the environmental impacts of freshwater thermal pollution from global power generation in LCA, Sci Total Environ, 580:1014-1026, https://doi.org/10.1016/j.scitotenv.2016.12.056

[14] Larrey-Lassalle P, Catel L., Roux P, Rosenbaum RK, Lopez-Ferber M, Junqua G, Loiseau E (2017). An innovative implementation of LCA within the EIA procedures: Lessons learned from two Wastewater Treatment Plant case studies, Environ Impact Assess Rev, 63:95-106, https://doi.org/10.1016/j.eiar.2016.12.004

[15] Goglio P, Smith WN, Grant BB, Desjardins RL, Gao X, Hanis K, Tenuta M, Campbell CA, McConkey BG, Nemecek T, Burgess PJ, Williams AG (2017). A comparison of methods to quantify greenhouse gas emissions of cropping system in LCA, J Clean Prod, In Press, Corrected Proof, 1-8

[16] Soust-Verdaguer B, Llatas C, García-Martínez A (2017). Critical review of bim-based LCA method to buildings, Energy and Buildings, 136:110-120, https://doi.org/10.1016/j.enbuild.2016.12.009

[17] Häfliger IF, John V, Passer A, Lasvaux S, Hoxha E, Saade MRM, Habert G (2017). Buildings environmental impacts' sensitivity related to LCA modelling choices of construction materials, J Clean Prod, 156:805-816, https://doi.org/10.1016/j.jclepro.2017.04.052

[18] Bicalho T, Sauer I, Rambaud A, Altukhova Y (2017). LCA data quality: A management science perspective, J Clean Prod, 156:888-898, https://doi.org/10.1016/j.jclepro.2017.03.229

[19] Del Pero F, Delogu M, Pierini M (2017). The effect of lightweighting in automotive LCA perspective: Estimation of mass-induced fuel consumption reduction for gasoline turbocharged vehicles, J Clean Prod, 154:566-577, https://doi.org/10.1016/j.jclepro.2017.04.013

[20] Islam H, Zhang G, Setunge S, Bhuiyan MA (2016). Life cycle assessment of shipping container home: A sustainable construction, Energy and Buildings, 128:673-685, https://doi.org/10.1016/j.enbuild.2016.07.002

[21] Zakeri B, Syri S (2015). Electrical energy storage systems: A comparative life cycle cost analysis, Renew and Sustainable Energy Rev, 42:569-596, https://doi.org/10.1016/j.rser.2014.10.011

[22] Barros JJC, Coira ML, López MPC, Gochi AC (2016). Probabilistic life-cycle cost analysis for renewable and non-renewable power plants, Energy, 112:774-787, https://doi.org/10.1016/j.energy.2016.06.098

[23] Tam VWY, Senaratne S, Le KN, Shen LY, Perica J, Illankoon IMCS (2017). Life-cycle cost analysis of green-building implementation using timber applications, J Clean Prod, 147:458-469, https://doi.org/10.1016/j.jclepro.2017.01.128

[24] Beltiukov V, Shehtman E, Malikov O (2017). Evaluation of effectiveness of separating layers in railroad track structure using life cycle cost analysis, Procedia Eng, 189:695-701, https://doi.org/10.1016/j.proeng.2017.05.110

[25] Meynerts L, Götze U, Claus S, Peças P, Riberio I (2017). Concept of integrated life cycle assessment and costing-Application to the case of designing a hybrid train, Procedia CIRP, 61:744-749, https://doi.org/10.1016/j.procir.2016.11.241

[26] Auer J, Bey N, Schäfer JM (2017). Combined life cycle assessment and life cycle costing in the EcoCare-Matrix: A case study on the performance of a modernized manufacturing system for glass containers, J Clean Prod, 141:99-109, https://doi.org/10.1016/j.jclepro.2016.08.096

[27] Jialong J, Sun S, Ren H (2016). Predictions of wave induced ship motions and loads by large-scale model measurement at sea and numerical analysis, Brodogradnja, 67(2):81-100, https://doi.org/10.21278/brod67206

[28] Sun S, Ren H, Zhao X, Li J (2015). Experimental study of two large-scale models' seakeeping performance in coastal waves, Brodogradnja, 66(2):57-60

[29] Sayli A, Alkan AD, Uysal AO (2014). Automatic elimination of ship design parameters based on data analysis for seakeeping performance, Brodogradnja, 65(4):15-33

[30] Suárez-Varela M, Espiñeira RM, Gómez GG (2015). An analysis of the price escalation of non-linear tariffs for domestic uses in Spain, Utilites Policy, 34:82-93, https://doi.org/10.1016/j.jup.2015.01.005

[31] Hecht JE (1997). Impacts of tariff escalation on the environment: Literature review and synthesis, World Dev, 25(10):1701-1716, https://doi.org/10.1016/S0305-750X(97)00064-8

[32] NATO (2007). Research and Technology Organization, Methods and Models for Life Cycle Costing, TRSAS-054

[33] NATO (2008). NATO Guidance on Life Cycle Cost, ALCCP-1 Ed. 1 
[34] NATO (2006). Allied Naval Engineering Publication ANEP-41 Ed.4, Ship Costing

[35] US Department of Defense (1983). Military Handbook, MIL-HDBK-259, Life Cycle Cost in Navy Acquisition

[36] Scientific Applications International Corporation (SAIC) (2006). Life Cycle Assessment: Principles and Practice, EPA/600/R-06/060

[37] UNEP (2006). Background report for a UNEP Guide to Life Cycle Management-A bridge to sustainable products, Editors: Jensen AA, Remmen A

[38] Sharma PD (2006). Life cycle Assessment (LCA)-A tool for quantifying sustainability and sound methodology for describing environmental impacts

[39] Kaliba C, Muya M, Mumba K (2009). Cost escalation and schedule delays in road construction projects in Zambia, Int J Proj Manage, 27:522-531, https://doi.org/10.1016/j.ijproman.2008.07.003

Submitted: $\quad$ 19.09.2017. Uğur Buğra Çelebi, ugur.celebi@gmail.com, Yildiz Technical University, Yildiz Campus, Barbaros Bulvarı, 34349, Beşiktaş/İstanbul

Accepted: $\quad$ 21.11.2018. $\quad$ Levent Bilgili, leventbilgili1661@ gmail.com, Bandirma Onyedi Eylul University, Yeni Mahalle Şehit Astsubay Mustafa Soner Varlık Caddesi, No: 77, 10200, Bandırma/Balıkesir

Bilkutay Y1lmaz, Undersecretariat for Defense Industries, Devlet Mahallesi Süleyman Emin Caddesi No:6-7, 06420, Çankaya/Ankara 